\title{
MORPHO-BIOLOGICAL FEATURES AND PRODUCTIVITY OF THE ARTICHOKE IN THE CONDITIONS OF THE SOUTH OF UZBEKISTAN
}

\author{
Muzaffar Khashimovich Aramov \\ Doctor of Agricultural Sciences, Professor, Termiz branch of Tashkent State Agrarian University, \\ Termiz, Uzbekistan \\ Bakhodir Khasanovich Aliev \\ Independent Researcher, Senior teacher, Termiz branch of Tashkent State Agrarian University, \\ Termiz, Uzbekistan
}

Article DOI: https://doi.org/10.36713/epra5114

\begin{abstract}
The article is dedicated to the results of research on the introduction of artichoke in the conditions of Uzbekistan. It was revealed that artichoke plants grow and develop well, form mature seeds during the growing season. The manifestation of morphobiological and farm-valuable traits largely depends on the age of the plants. A significant reduction in the growth period, an increase in plant height and number of stems, an increase in average weight and number of inflorescences and, ultimately, the yield occur in the second year of plant life. It was also determined that the potential productivity of artichoke plants in the condition of Uzbekistan is very high. The yield of the cultivar Krasavets is $55.5 \mathrm{t} / \mathrm{ha}$ in the second year of life, for the Green Globe cultivar - 39.2 t/ ha. This is significantly higher worldwide.

During the research, some issues of artichoke seed production in the dry subtropics of Uzbekistan were also studied. The studies were carried out on the cultivar Krasavets. When identifying the most effective method of forming a seed cluster, we compared the cultivation of seed plants without formation and 4 methods of formation: 1 stem per plant and three inflorescences per stem, 2 stems per plant and three inflorescences each, 3 stems per plant and three inflorescences each, 4 stems per plant and three inflorescences each. The highest seed productivity was noted in the variant without the formation of a seed plant: $734.2 \mathrm{~g} /$ plant or 15789 seeds/ plant. However, in terms of such indicators as the mass and number of seeds from one inflorescence, the mass of 1000 seeds of a plant without formation is significantly inferior to other options. Based on the results of experience, the variants 3, 4, 5 can be considered appropriate to use in artichoke seed production.
\end{abstract}

KEYWORDS: artichoke, phenology, inflorescence, productivity, mass and number of inflorescences, interphase periods, growing season, plant height, seed production.

\section{INTRODUCTION}

Artichoke (Cynara cardunculus I. subsp. scolumus (L.), Науек.) is native to Mediterranean, where its wild population is still occupy vast area. Since the XYI XYII centuries, the artichoke has been cultivated in all Mediterranean countries $[1,2]$.

Artichoke is a plant of the Asteraceae family, widespread in almost all Mediterranean countries, as well as in France, Spain, the USA, Canada, Argentina and so on. It is cultivated in the southern regions of Russia - in the Krasnodar territory and in the North Caucasus [2].

According to the data of FAO, in 2013 the artichoke sown area in the world amounted to 0.131 million hectares, the average yield was $13.72 \mathrm{t} / \mathrm{ha}$, and the volume of gross production reached 1.793 million 


\title{
EPRA International Journal of Research and Development (IJRD)
}

\author{
Volume: 5 | Issue: 9 | September 2020 \\ - Peer Reviewed Journal
}

tons. Large artichoke producers are Italy -0.548 million tons, Egypt - 0.391 million tons, Spain -0.200 million tons, Peru -0.113 million tons, Argentina - 0.106 million tons [3].

The highest yield was recorded in Argentina (24.93 t/ha), Egypt (24.10 t/ha), Cyprus (20.60 t/ha), Kazakhstan (20.0 t/ha), Peru (19.30 t/ha). California is the main artichoke producer in the United States.

In European countries, a lot of attention is paid to breeding, seed production, genetics, the development of advanced technologies for growing artichoke. In 2008, a project was launched called "European genetic resources of Cynara ssp." [4]. The project coordinated by the University of Tuscia (Italy) has 7 partners - three Italian (Tuscia University, CNP, ENEA), two French (BBV, GEVES) and two Spanish (Cartagena University, ITGA). The project conducts research in five areas:

1. collection of germplasm and rationalization of collection;

2. preservation of plants and DNA and their reproduction;

3. evaluation and characterization of germplasm;

4. an interactive web catalog of documentation;

5. Cynares network implementation and actions.

Only in the first area under the leadership of Dc. Macua (ITGA), 196 lines of artichoke, 34 samples of cardoon and 55 samples of wild cardoon were collected.

Much of the research on artichoke, cardoon and their wild relatives is carried out in accordance with this project.

To coordinate the work of scientists, artichoke producers and to solve the problem of this culture, the symposia are held in different countries of the world every 3 years.

The Seventh International Symposium on artichoke, cardoona and their wild congeners was held from 16 to 19 June in 2009 in the small town of Plouenan, near Saint-Polde Leon, Brittany, France.

The choice of the venue for the symposium is not accidental, since 1890 Saint-PoldeLeon has been the largest center for the production of artichoke (70\%) and cauliflower (90\%) in France [5].

The IX-Symposium was held in 2015 in Argentina, the X-in 2019 in Spain. From the analysis of the works presented at these symposia, it follows that the selection work is most intensively carried out with an artichoke of the Romanesco type. The joint work of scientists from Italy, Spain and the USA made it possible to obtain promising $F_{1}$ hybrids on the basis of male sterility, the maintenance of which does not require biotechnological methods.

The artichoke is a dietary vegetable. It contains protein, carbohydrates, vitamins A, B, P, cynarin, inulin, fiber and other elements necessary for the human body. The use of artichoke in cooking is very varied: it is served both as a main dish and as a side dish. Pizza and salads are made from it, added to pies and bread. Some restaurants make desserts from it [6].
As a vegetable, ornamental, fodder, melliferous and medicinal plant, the artichoke is of great interest as a potential introducer in the conditions of Uzbekistan.

Previously, studies were carried out on two cultivars of artichoke in the conditions of southern Uzbekistan [7]. To the mind of the authors, the varietal characteristics of the reaction of the artichoke to the conditions of introduction were not revealed. All plants after sowing grew rapidly, developed normally and gave full seeds in the first year of life. However, further research with this culture was discontinued.

\section{MATERIALS AND METHODS}

In 2018-2019 at the Surkhandarya scientific experimental station of the Research Institute of vegetable, melon and potato growing, the studies were carried out on the introduction of the artichoke.

The objects of research were the cultivars Krasavets (Russia) (Spinosi group) and GreenGlobe (Spain) (Romanesco group). The Romanesco group includes cultivars with spherical or close to spherical inflorescences, without sharp protrusions on the bracts and leaves. The Spinosi group includes varieties that have long, sharp projections on the bracts and leaves.

The seeds were sown on November 15, 2017 and 2018 in unheated film greenhouses. Seedlings were transplanted in the phase of 5-6 true leaves in the first decade of February. Planting scheme was 1x1 m size.

During the growing season, phenological observations, morphological description of plants, and yield accounting were carried out according to the method $[8,9]$.

\section{RESULTS AND DISCUSSION}

Introductions have played an outstanding role in the history of world agriculture. Suffice it to say that countries such as the USA, Canada, Australia built their agriculture almost entirely on the introduction of foreign plants and animals $[10,11,12]$.

The introduction in Uzbekistan is associated with the appearance of tomato, sweet pepper, potato and a number of other important agricultural crops, without which it is difficult to imagine our life now.

A promising direction is the introduction of new valuable species of vegetable plants, widely cultivated in various countries of the world, but little-known and therefore less widespread in Uzbekistan. These crops include the artichoke, known for its nutritional and healing properties.

The problems of plant introduction, solution of the problems of growth and successful development of plants in various soil and climatic conditions are extremely relevant issue today [13].

This article presents some of the results of research on the introduction of artichoke in the dry subtropics of Uzbekistan.

When sowing artichoke seeds in unheated film greenhouses on November 15, 2017 and 2018, single shoots of the cultivar Krasavets appeared on November 
27 , i.e. on the $12^{\text {th }}$ day after sowing, and mass shoots appeared on December 4 and on the $20^{\text {th }}$ day, respectively. In the GreenGlobe cultivar, single shoots appeared on the $15^{\text {th }}$ and mass shoots on the $22^{\text {nd }}$ day from sowing (Table 1).

Table 1

Dates of phenological phases of the development of artichoke depending on the age of the plant, in 2017-2019

\begin{tabular}{|c|c|c|c|}
\hline \multirow{2}{*}{\multicolumn{2}{|c|}{ Developmental phases }} & \multicolumn{2}{|c|}{ Cultivars } \\
\hline & & Krasavets & GreenGlobe \\
\hline \multicolumn{4}{|c|}{ I-year of life } \\
\hline \multirow[t]{2}{*}{ Shoots } & \multirow{2}{*}{$\begin{array}{l}10 \% \\
75 \%\end{array}$} & 27.11 .2017 & 30.11 .2017 \\
\hline & & 04.12 .2017 & 06.12 .2017 \\
\hline \multirow[t]{2}{*}{ Repiness } & \multirow{2}{*}{$\begin{array}{l}10 \% \\
75 \%\end{array}$} & 10.06 .2018 & 20.06 .2018 \\
\hline & & 15.06 .2018 & 28.06 .2018 \\
\hline \multirow{2}{*}{ Flowering } & \multirow{2}{*}{$\begin{array}{l}10 \% \\
75 \%\end{array}$} & 20.06 .2018 & 30.06 .2018 \\
\hline & & 26.06 .2018 & 05.07 .2018 \\
\hline \multirow[t]{2}{*}{ Full ripeness } & \multirow{2}{*}{$\begin{array}{l}10 \% \\
75 \%\end{array}$} & 21.07 .2018 & 30.07 .2018 \\
\hline & & 28.07.2018 & 10.08 .2018 \\
\hline \multicolumn{4}{|c|}{ II-year of life } \\
\hline \multicolumn{2}{|l|}{ Regrowth } & 25.01 .2019 & 25.01 .2019 \\
\hline \multirow[t]{2}{*}{ Ripeness } & \multirow{2}{*}{$\begin{array}{l}10 \% \\
75 \%\end{array}$} & 30.04 .2019 & 05.05 .2019 \\
\hline & & 06.05 .2019 & 10.05 .2019 \\
\hline \multirow[t]{2}{*}{ Flowering } & \multirow{2}{*}{$\begin{array}{l}10 \% \\
75 \%\end{array}$} & 10.05 .2019 & 15.05 .2019 \\
\hline & & 18.05 .2019 & 22.05 .2019 \\
\hline Full ripeness & $10 \%$ & 16.06 .2019 & 20.06 .2019 \\
\hline
\end{tabular}

Depending on the age of the plants, the dates of onset and the duration of the subsequent interphase periods of the artichoke differ significantly.

In the first year of life, the beginning of the ripeness of the inflorescences (flower head) of the Krasavets variety occurs on June 10 , full ripeness on June 15. In the second year of life, the onset of these phases of development occurs on April 30 and May 6, respectively. In the GreenGlobe variety, the beginning of ripeness of inflorescences in the first year of life begins on June 20, mass ripening on June 28.

Mass flowering of Krasavets cultivar of artichoke plant in the first year of life occurs on June 26, and in the second year - on May 18. In the second year of life, the onset of this phase occurs 38 days earlier than in the first year. Mass flowering of GreenGlobe cultivar of artichoke plants occurs on July 5 in the first year of life, while in the second year - on May 22. In the second year of life, the onset of this phase occurs 43 days earlier than in the first year.

When comparing the duration of the interphase periods of plants in the first and in the second year of life, it was found that in the second year of life it is significantly reduced.
In the first year of life, the period from mass shoots to the beginning of ripeness in the studied varieties made 190-197 days (Table 2). In the second year of life, the duration of this period constituted 96101 days and decreased by 94-96 days compared to the first year of life.

This feature can be used to ensure an even supply of the artichoke crop to retail chains. First, the harvest comes from the second year crop, and then from the first years.

The period from mass shoots to the beginning of full ripeness (i.e., to seed ripening), depending on the variety, makes 231-237 days in the first year of life, while in the second year, it is 143-147 days. In the second year of life, this period is reduced by 88-90 days.

Depending on the age of artichoke plants, the morpho-biological characteristics also differ significantly (Table 3 ). So, in the first year of life, the height of plants of the Krasavets variety was $110 \mathrm{~cm}$, and in the second year $-216 \mathrm{~cm}$. The same phenomenon was observed in the GreenGlobe cultivar.

If the plants of the Krasavets variety in the first year of life form 1-2 branches, then in the second year they are 2-4 pieces. At the same time, GreenGlobe plants do not form branches regardless of age. 


\section{EPRA International Journal of Research and Development (IJRD)}

Table 2

Duration of phonological phase of the development of artichoke in the conditions of the south of Uzbekistan, in 2017-2019

\begin{tabular}{|c|c|c|c|c|c|}
\hline \multirow{2}{*}{ Cultivars } & \multicolumn{5}{|c|}{ From mass shoots, days } \\
\cline { 2 - 5 } & $\begin{array}{c}\text { Before the } \\
\text { beginning of } \\
\text { ripeness }\end{array}$ & $\begin{array}{c}\text { Before mass } \\
\text { ripeness }\end{array}$ & $\begin{array}{c}\text { Before the } \\
\text { beginning of } \\
\text { flowering }\end{array}$ & $\begin{array}{c}\text { Before mass } \\
\text { flowering }\end{array}$ & $\begin{array}{c}\text { Before full } \\
\text { ripeness }\end{array}$ \\
\hline \multicolumn{5}{|c|}{ I-year of life } \\
\hline Krasavets & 190 & 195 & 200 & 206 & 231 \\
\hline GreenGlobe & 197 & 205 & 207 & 212 & 237 \\
\hline \multicolumn{7}{|c|}{ II - year of life (from the beginning of regrowth) } \\
\hline Krasavets & 96 & 102 & 106 & 114 & 143 \\
\hline GreenGlobe & 101 & 107 & 111 & 118 & 147 \\
\hline
\end{tabular}

The most significant differences were, in our opinion, in the number of inflorescences (flower heads). Thus, the plants of the Krasavets variety in the first year of life form from 10 to 28 inflorescences, and in the second year - from 36 to 67 . The number of inflorescences of plants of the GreenGlobe variety is significantly less than in the Krasavets variety. In the GreenGlobe variety, the plants formed 9-20 inflorescences in the first year of life, while in the second year of life, they were 11-24.

The most important indicator that ultimately determines the yield is the average weight of the inflorescences. Thus, in the cultivar Krasavets in the first year of life, the average weight of inflorescences in the ripeness phase was $98 \mathrm{~g}$, and in the second year, 121 g. In the GreenGlobe cultivar, these indicators were, respectively: $202 \mathrm{~g}$ and $215 \mathrm{~g}$. In the second year of life, the plants formed larger inflorescences.

Depending on the age of the plants, the yield of the artichoke was different. Thus, in the first year of life the productivity of the plants of Krasavets cultivar was 1.96 $\mathrm{kg}$, which in terms of an ideal hectare was $19.6 \mathrm{t} / \mathrm{ha}$. The same indicators in the second year of life were respectively: $5.55 \mathrm{~kg} / \mathrm{plant}$ and $55.5 \mathrm{t} / \mathrm{ha}$. The productivity of GreenGlobe variety in the first year of life was $2.97 \mathrm{~kg}$, which was $29.7 \mathrm{t} / \mathrm{ha}$ per ideal hectare. In the second year of life, the indicators were $3.92 \mathrm{~kg} /$ plant and $39.2 \mathrm{t} /$ ha respectively.

In the process of research, some issues of artichoke seed production in the dry subtropics of Uzbekistan were also studied (Table 4). When identifying the most effective method for the formation of a seed plant, we compared the cultivation of seed plants without formation and 4 methods of formation: 1 stem on a plant and 3 inflorescences on a stem, 2 stems on a plant and three inflorescences on each, 3 stems on a plant and three inflorescences on each, 4 stems per plant and 3 inflorescences on each.

Table 3

Morpho-biological traits of artichoke depending on the age of plant, in 2018-2019

\begin{tabular}{|c|c|c|c|c|}
\hline \multirow{3}{*}{ Traits } & \multicolumn{4}{|c|}{ Cultivars } \\
\hline & \multicolumn{2}{|c|}{ Krasavets } & \multicolumn{2}{|c|}{ GreenGlobe } \\
\hline & I-year of life & II-year of life & I-year of life & II-year of life \\
\hline Plant height, $\mathrm{cm}$ & 110 & 216 & 93 & 155 \\
\hline Numbr of branches, pcs & $1-2$ & $2-4$ & 1 & 1 \\
\hline $\begin{array}{l}\text { Number of inflorescences (flower } \\
\text { heads), pcs }\end{array}$ & $10-28$ & $36-67$ & $9-20$ & $11-24$ \\
\hline $\begin{array}{l}\text { Mass of inflorescences (flower heads) } \\
\text { in ripeness phase, g }\end{array}$ & 98 & 121 & 202 & 215 \\
\hline Plant productivity, kg/plant. & 1.96 & 5.55 & 2.97 & 3.92 \\
\hline
\end{tabular}


Table 4

Productivity and quality of artichoke seeds with different methods of formation of seed plant, in 2018-2019

\begin{tabular}{|l|c|c|c|c|c|}
\hline \multicolumn{1}{|c|}{$\begin{array}{c}\text { Methods of formation of } \\
\text { seed plant }\end{array}$} & $\begin{array}{c}\text { Seed } \\
\text { productivity } \\
\text { of a plant, }\end{array}$ & $\begin{array}{c}\text { Mass of seeds } \\
\text { from one } \\
\text { inflorescence, g }\end{array}$ & $\begin{array}{c}\text { Mass of } \\
\mathbf{1 0 0 0} \\
\text { seeds, g }\end{array}$ & $\begin{array}{c}\text { From one } \\
\text { plant }\end{array}$ & $\begin{array}{c}\text { from one } \\
\text { inflorescence }\end{array}$ \\
\hline Control - without formation & 734.2 & 15.0 & 46.5 & 15789.0 & 322.2 \\
\hline $\begin{array}{l}\text { 1 stem on a plant and 3 } \\
\text { inflorescences on a stem }\end{array}$ & 102.7 & 34.2 & 54.6 & 1881.0 & 627.0 \\
\hline $\begin{array}{l}\text { 2 stems on a plant and 3 } \\
\text { inflorescences on each }\end{array}$ & 179.7 & 30.0 & 54.8 & 3279.0 & 546.5 \\
\hline $\begin{array}{l}\text { 3 stems on a plant and 3 } \\
\text { inflorescences on each }\end{array}$ & 246.5 & 27.4 & 67.6 & 3648.0 & 405.3 \\
\hline $\begin{array}{l}\text { 4 stems on a plant and 3 } \\
\text { inflorescences on each }\end{array}$ & 270.1 & 22.5 & 47.1 & 5735.0 & 477.9 \\
\hline
\end{tabular}

The highest seed productivity was noted in the variant without the formation of a seed plant: 734.2 g/plant or 15789 seeds/plant. Comparatively higher seed productivity was noted in the variants 3,4 and 5 of the experiment. Seed productivity of plants in these variants was $179.7,246.5,270.1 \mathrm{~g}$, respectively. This is $24.5-$ $36.8 \%$ compared to the control. However, in terms of such indicators as the mass and number of seeds from one inflorescence, the mass of 1000 seeds of a plant without formation is significantly inferior to other variants. Based on the results of experience, the variants $3,4,5$ can be considered appropriate to use in artichoke seed production.

Research has shown that in the conditions of southern Uzbekistan there is potential for the cultivation of artichoke seeds with high sowing quality.

\section{CONCLUSION}

Thus, for the first time in Uzbekistan, the morphobiological and farm- valuable traits of the artichoke have been studied. The research results showed that the artichoke is a valuable food product for the conditions of Uzbekistan and its introduction allows us to expand the range of cultivated vegetable crops.

Phenological observations made it possible to determine the specific and varietal reactions to the onset and duration of phenological phases, the rhythm of development of artichoke plants at different sowing dates.

In the conditions of the southern Uzbekistan, there is potential for the cultivation of high-quality artichoke seeds.

\section{REFERENCES}

1. Pivovarov V.F. (2006). Vegetables of Russia. Moscow, pp.116-118. (In Russian)

2. Kornienko S. (2011). Artichoke - delicious vegetable. Vegetable growing and greenhouse farming (the Ukraine), No 4, pp. 19-25. (In Russian)

3. FAOSTAT.

2013.
4. Pagnotta M.A. (2009). The European Project: European Genetic Resources of Cynara ssp. $7^{\text {th }}$ International Symposium on artichoke. Saint Pol de Leon, France. June 17 th $-19^{\text {th }}$, pp. 3.

5. Krivenkov L.V. (2009). The seventh international symposium on artichoke, cardoon and their wild relatives. Vegetables of Russia, No 3(5), pp. 56-59. (In Russian)

6. Artichoke - application, useful properties, cultivation, care. https://divodacha.ru/ogorod/artishok-primenenie-poleznyesvojstva-vyrashhivanie-uxod/ (In Russian)

7. Pivovarov V.F., Dobrutskaya E.G. (2000). Ecological bases of selection and seed production of vegetable crops. Moscow, pp. 134-135. (In Russian)

8. Crop Testing Guide. (1948). Volume V. Vegetable crops and fodder root crops. Moscow, Leningrad. pp. 222-224. (In Russian)

9. Methodology for distinctness, uniformity and stability. Artichoke (Cynara cardunculus I., subsp. scolumus (L.), Науeк.). (In Russian)

10. Vavilov N.I. (1966). Genetics and breeding. Selected works, Moscow. (In Russian)

11. Brezhnev D.D. (1971). The state and objectives of the introduction of vegetable and melon crops in the USSR. Works on applied botany, genetics and selection. Leningrad, T. 45, edit. 1. pp. 3-18. (In Russian)

12. Brezhnev D.D. (1975). The flagship of Soviet crop production. Works on applied botany, genetics and selection, No 56(1), pp. 8-25. (In Russian)

13. Kuznetsova A.M., Kuznetsova O.I. (1998). Factors of growth and development of vegetable crops. In: Introduction of non-traditional and rare agricultural plants. Materials of the AllRussian scientific production. conf. May 24-28, 1998, Penza. pp.157-160. (In Russian) http://www.fao.org/faostat/en/\#data/QC 